\title{
DIAGNOSIS LIMA PENYAKIT UTAMA KARENA JAMUR PADA 100 KULTIVAR BIBIT PISANG
}

\author{
Loekas Soesanto ${ }^{1}$, Endang Mugiastuti ${ }^{1}$, Fajarudin Ahmad ${ }^{2}$ \& Witjaksono $^{2}$ \\ ${ }^{1)}$ Jurusan Hama dan Penyakit Tumbuhan, Fakultas Pertanian, Universitas Jenderal Soedirman \\ E-mail:lukassus26@gmail.com \\ ${ }^{2)}$ Lembaga Ilmu Pengetahuan Indonesia (LIPI), Bogor
}

\begin{abstract}
Diagnosis of five main diseases caused by fungi on 100 banana seedling cultivars. The research which aimed to identify main pathogenic fungi of 100 banana seedling cultivars and their disease intensity was carried out at the Laboratory of Plant Disease, Faculty of Agriculture, Jenderal Soedirman University with samples and field data taking at Indonesian Insitute of Science Bogor. This descriptive research was started by taking samples and field data followed by identification of pathogenic fungi at the laboratory. Variables observed were disease symptoms, colony and pathogenic morphology, kinds of the pathogen, disease intensity, and physical data. Result of the research showed that there were five main pathogenic fungi of the banana seedlings, i.e., Fusarium oxysporum Schlecht. f.sp. cubense, causing Fusarium wilt; Mychosphaerella musicola Mulder, causing Mycosphaerella leaf spot or Sigatoka; Cordana musae (Zimm.) Hohn., causing Cordana leaf spot; Curvularia lunata, causing leaf spot; and Cladosporium musae Mason, causing speckle. From 100 banana seedling cultivars observed, Fusarium oxysporum f.sp. cubense was the most frequently found with the intensity of 1.4-72\%, followed by Curvularia lunata, Mychosphaerella musicola, Cladosporium Musae, and Cordana musae with the intensity of 1-32, 2-18, 2-24, and 3$23 \%$, respectively.
\end{abstract}

Key words: identification, disease intencity, leaf pathogen, banana seedling

\section{ABSTRAK}

Diagnosis lima penyakit utama karena jamur pada 100 kultivar bibit pisang. Penelitian tentang identifikasi jamur patogen daun utama dari 100 kultivar bibit pisang dan intensitas serangannya dilakukan di Laboratorium Penyakit Tumbuhan, Fakultas Pertanian Universitas Jenderal Soedirman dengan pengambilan sampel dari 100 kultivar bibit pisang dan data lapangan di Lembaga Ilmu Pengetahuan Indonesia, Bogor. Penelitian deskriptif ini dimulai dengan pengambilan sampel dan data lapangan, kemudian jamur patogen diidentifikasi di laboratorium. Variabel yang diamati adalah gejala, morfologi koloni dan patogen, jenis patogen, intensitas penyakit, dan data fisik. Hasil penelitian menunjukkan bahwa ada lima jenis jamur patogen utama bibit pisang, yaitu Fusarium oxysporum Schlecht. f.sp. cubense, penyebab layu Fusarium; Mychosphaerella musicola Mulder, penyebab bercak daun Mycosphaerella atau Sigatoka; Cordana musae (Zimm.) Hohn., penyebab bercak daun Cordana; Curvularia lunata, penyebab bercak daun; dan Cladosporium musae Mason, penyebab burik. Pada 100 kultivar bibit pisang yang diamati, Fusarium oxysporum f.sp. cubense yang terbanyak dijumpai dengan intensitas penyakit 1,4-72\%, diikuti Curvularia lunata sebesar 1-32\%, Mychosphaerella musicola sebesar 2-18\%, Cladosporium musae sebesar 2-24\%, dan Cordana musae sebesar 3-23\%.

Kata kunci: identifikasi, intensitas penyakit, patogen daun, bibit pisang

\section{PENDAHULUAN}

Produksi pisang dari tahun ke tahun mengalami peningkatan. Meningkatnya permintaan buah pisang untuk kebutuhan lokal maupun untuk ekspor diikuti dengan meningkatnya kebutuhan akan bibit pisang berkualitas.

Pertumbuhan tanaman pisang selalu diganggu oleh serangan organisme pengganggu tanaman, baik di pembibitan maupun di lapangan. Adanya penyakit pada daun dapat mengurangi fotosintesis, sehingga mengganggu pertumbuhan dan perkembangan tanaman (Kistler, 1997; Smith, 2007). Tanaman pisang rakyat seperti kultivar ambon, barangan, dan kepok banyak yang rusak oleh penyakit tanaman (Hermanto \& Setyawati, 2002). Salah satu kelompok organisme pengganggu tanaman yang menyebabkan penyakit pada pisang adalah jamur patogen. Jamur menyebabkan gejala lokal 
atau sistemik pada inangnya, dan gejala tersebut mungkin terjadi secara terpisah pada inang berbeda, secara bersamaan pada inang sama, atau yang satu mengikuti yang lain pada inang yang sama.

Beberapa jamur patogen yang menyebabkan penyakit pada daun pisang, antara lain Fusarium oxysporum Schlecht f.sp. cubense penyebab penyakit layu Fusarium, Mycosphaerella musicola Mulder penyebab becak daun Mycosphaerella yang dikenal sebagai penyakit Sigatoka, Cordana musae (Zimm.) Hohn penyebab becak daun Cordana, Phaeoramularia musae penyebab burik, Colletotrichum musae (Berk. et Curt.) Arx penyebab antraknosa, Uredo musae Cummins penyebab karat daun, Drechslera gigantean (Heald et Wolf) Ito penyebab becak mata, Guignardia musae Rac. penyebab bintik-bintik pada daun, Phyllachora musicola Booth et Shaw. penyebab becak palang hitam, dan lainnya (Ploetz, 2007; Smith, 2007). Diagnosis penyakit pada bibit pisang jarang dilakukan, khususnya dalam jumlah kultivar yang banyak. Oleh karena itu, perlu dilakukan identifikasi untuk menentukan jamur patogen yang menyebabkan penyakit pada bibit pisang.

Penelitian bertujuan untuk mengidentifikasi lima jamur penyebab penyakit utama pada pisang dari 100 kultivar bibit pisang dan mengetahui intensitas serangan masing-masing penyakit utama pada 100 kultivar bibit pisang.

\section{BAHAN DAN METODE}

Tempat dan Waktu. Penelitian dilaksanakan di Laboratorium Penyakit Tumbuhan Fakultas Pertanian Universitas Jenderal Soedirman. Sampel daun pisang bergejala penyakit diambil dari 100 kultivar bibit pisang (umur 7 bulan) di pembibitan Lembaga Ilmu Pengetahuan Indonesia (LIPI) Bogor. Penelitian dilaksanakan dari April sampai Juni 2008.

Penyiapan sampel. Sampel berupa daun bergejala penyakit disiapkan dari 100 kultivar bibit pisang dibagi menjadi dua kelompok, yaitu kelompok koleksi dan kelompok oryzalin.

Kelompok koleksi. Terdiri atas ITC $0673 \mathrm{Sa}$, ITC 0269 Niyarma Yik, ITC 0281 Akondro Mainty, ITC 0294 Pitu, ITC 0375 Undu Jamau, ITC 0392 Datil, ITC 0432 Pamoti-on, ITC 0679 Pisang Sapon, ITC 0689 Pisang Bangkahulu, ITC 0715 Samba, AB Kunan, Ambon Mandar, B2 x E12 (E1), B2 x E12 (E2), Barangan \#1, Barangan \#2, Barangan diploid, Dingin Lidi, Dwarf
Cavendish, Dwarf Perfit, Jari Buaya \#2, Jari Buaya “"1, Kadali, Kapas, Kepok \#1, Kepok Jogja, Kepok Kuning Yogya, Kesan Pisan \#1, Kesan Pisan \#2, Klutuk Sukun \#1, Klutuk Sukun \#2, Klutuk Wulung, Mas 40 Hari, Mas Jambe, Mas Jember, Mas Muli, Musa acuminaata var. malaccensis \#1, Musa acuminata var banksii \#2.1, Musa acuminata var banksii \#2.2, Musa acuminata var. sumatrana, Musa acumninata var malaccensis \#2.1, Musa acumninata var malaccensis \#2.2, Ney Poovan, Pisang Lampung, Raja Bulu, Raja Dengkel, Raja Sewu, Raja Susu, Rejang \#2, Siam, dan Ustrali Banten

Kelompok oryzalin. Terdiri atas ITC 0258 Pisang Madu, ITC 0258 Yangambi, ITC 0260 Colatina Ouro, ITC 0266 Sowmuk, ITC 0279 Bie Yeng, ITC 0281 Akondro Mainty, ITC 0299 Guyod, ITC 0320 Paka, ITC 0375 Undu Jamau, ITC 0392 Datil, ITC 0432 Pamotion, ITC 0442 Gu Nin Chio, ITC 0470 Posok, ITC 0471 Bebek, ITC 0507 Pisang Madu, ITC 0553 2390-2, ITC 0610, Tuu Gia, ITC 0679 Pisang Sapon, ITC 0777 Pitu, ITC 0840 Kuspaka, ITC 0936 Musa acuminata var. banksii, ITC 0974 Bata bata, ITC 0975 Pisang Gu Nin Chio, ITC 0989 Tagamor, ITC 0990 Vunapope, ITC 1004 To'o, ITC 1031 Veinte Cohol, ITC 1150 Morong princesa, ITC 1253 Mjenga "Gros Michel" diploid, ITC 1455 Mshale Mlelembo, ITC 1456 Huti rb, Mas 40 Hari, Jari Buaya, Klutuk, Klutuk Wulung, Mas Lumut, Musa acuminata var banksii \#5.1, Musa acuminata var banksii \#5.2, Mas Pinang, Rejang \#2, Mas Jalil, Mas Mangga, Mas Penjalin, Mas Rejang, Mas Rojo, Klutuk Sukun, Klutuk Warangan, Mas Sapoyono, Rejang \#1, dan Musa acuminata var. banksii \#3

Pengisolasian jamur patogen. Sampel daun bibit pisang bergejala penyakit didiagnosis dan jamur patogen diisolasi pada medium PDA yang telah disiapkan. Sampel daun tanaman pisang bergejala disterilkan permukaannya dengan alkohol 70\% selama 3-5 menit, dibilas dua kali dengan menggunakan air steril, dan ditiriskan pada selampai hingga kering. Selanjutnya, daun tersebut dipotong dengan ukuran $\pm 0,5 \times 0,5 \mathrm{~cm}^{2}$ menggunakan skalpel tajam steril, dengan mengikutsertakan bagian yang sakit dan yang sehat. Secara aseptis, potongan daun pisang tersebut dimasukkan ke dalam cawan Petri yang telah berisi PDA padat dengan pinset steril dan diberi label. Cawan Petri diinkubasi pada suhu kamar selama 3-5 hari dan jamur yang tumbuh siap untuk diidentifikasi (Urdaneta et al., 2002). Penelitian menggunakan rancangan deskriptif. 
Pengidentifikasian. Jamur patogen diamati di bawah mikroskop dengan perbesaran rendah dan dibandingkan dengan beberapa pustaka, seperti Barnett \& Hunter (1972) dan Ulloa \& Hanlin (2000).

Pengamatan dan pengukuran. Pengamatan dilakukan terhadap gejala lima penyakit utama pada 100 jenis bibit pisang dengan 2 kali ulangan. Intensitas penyakit untuk semua gejala dihitung dengan rumus:

$\mathrm{IP}=\mathrm{a} / \mathrm{b} \times 100 \%$

dengan,

$\mathrm{IP}=$ intensitas penyakit,

$a=$ luas daun terserang, dan

$b=$ luas total daun.

Pengamatan morfologi koloni dilakukan dengan melihat warna dan tepi koloni jamur patogen yang tumbuh dalam cawan Petri di bawah mikroskop. Pengamatan morfologi patogen antara lain dilakukan terhadap warna, sekat, dan dinding konidium di bawah mikroskop serta diukur. Pengamatan data iklim meliputi suhu, kelembapan udara, dan intensitas sinar matahari dilakukan di lokasi pembibitan.

\section{HASIL DAN PEMBAHASAN}

Pengamatan Gejala. Hasil pengamatan gejala lima penyakit utama pada 100 bibit pisang adalah sebagai berikut.

1. Penyakit layu Fusarium. Gejala yang tampak pada tanaman adalah tepi daun bawah berwarna kuning tua, dimulai dari tepi daun bagian pangkal (Gambar 1A). Daun bergejala kemudian menjadi coklat dan mengering. Hal ini sesuai pendapat Nasir et al. (2003b) dan Dita et al. (2010), yang menyatakan bahwa gejala penyakit layu Fusarium dimulai dengan penguningan dan pelayuan daun tua, yang berkembang ke daun lebih muda sampai akhirnya seluruh tanaman mati. Secara internal, tanaman dengan infeksi yang berlanjut memperlihatkan perubahan warna pada rizome dan nekrosis pada silem. Gejala penyakit berkembang sangat cepat pada kondisi yang sesuai untuk pertumbuhan tanaman pisang dan gejala kelihatan jelas pada 2-5 bulan sesudah infeksi pertama (Jegger et al., 1995).

\section{Penyakit bercak daun Mycosphaerella. Gejala} pertama penyakit bercak daun Mycosphaerella, yang dikenal sebagai "penyakit Sigatoka", adalah pada daun ke-3 dan ke-4 dari puncak, yang ditandai dengan bintik memanjang, berwarna kuning pucat atau hijau kecoklatan, panjangnya 1-2 mm atau lebih, arahnya sejajar dengan tulang daun, dan berbentuk tidak teratur (Gambar 1B). Sebagian bintik tersebut berkembang menjadi becak berwarna coklat tua sampai hitam, berbentuk jorong atau bulat panjang, yang panjangnya 1 $\mathrm{cm}$ atau lebih, lebarnya lebih kurang sepertiga dari panjangnya (Goodwin et al., 2001; Crous, 2009).

3. Penyakit bercak daun Cordana. Gejala penyakit bercak daun Cordana yang tampak pada daun adalah mula-mula timbul becak berbentuk jorong atau bulat telur, kadang-kadang berbentuk berlian, yang kemudian membesar, dan berwarna coklat pucat, dengan bagian tepi berwarna coklat kemerahan, yang dikelilingi oleh halo berwarna kuning cerah (Gambar 1C). Apabila yang terinfeksi tepi daun, becak dapat berbentuk sabit, yang kemudian dapat memanjang menjadi coreng berwarna coklat pucat, yang dapat meluas sampai ibu tulang daun. Hal ini sesuai dengan pendapat Photita et al. (2004) dan Soares et al. (2005) bahwa beberapa patogen, termasuk $C$. musae penyebab penyakit bercak daun Cordana, selalu dijumpai pada daun pisang sebagai jamur endofit dan bersifat parasit.

4. Penyakit bercak daun Curvularia. Gejala penyakit bercak daun Curvularia ditunjukkan dengan adanya bintik coklat kehitaman, yang berkembang menjadi becak jorong, dengan tepi coklat kehitaman, dan di bagian tengahnya terdapat bundaran berwarna kelabu tua atau coklat (Gambar 1D). Bercak dikelilingi halo berwarna kuning, yang sesuai dengan pendapat Photita et al. (2001), bahwa beberapa endofit adalah patogen laten pada tanaman pisang.

5. Penyakit burik (speckle). Penyakit burik (speckle) memperlihatkan gejala pada daun terdapat becak kecil berwarna coklat tua sampai hitam, yang mengumpul pada jarak yang hampir sama (Gambar 1E). Ukuran masingmasing becak adalah sebesar kepala jarum dan kemudian berkembang menguasai daerah yang luas dari permukaan daun yang berfotosintesis. Tanaman yang terserang terutama pada daun yang sudah tua (Photita et al., 2004; Crous et al., 2005).

Pengamatan Morfologi Koloni. Koloni F. oxysporum f.sp. cubense mempunyai warna putih, seperti kapas (Gambar 2A), dengan koloni membentuk banyak sporodokium yang menghasilkan banyak mikrokonidium. Hal ini sesuai dengan pendapat Smith (2007), yang mengatakan bahwa koloni $F$. oxysporum f.sp. cubense berwarna putih yang menghasilkan sporodokium. Sementara itu, koloni M. musicola berwarna berwarna hijau zaitun kehitaman (Gambar 2B), yang sesuai dengan 

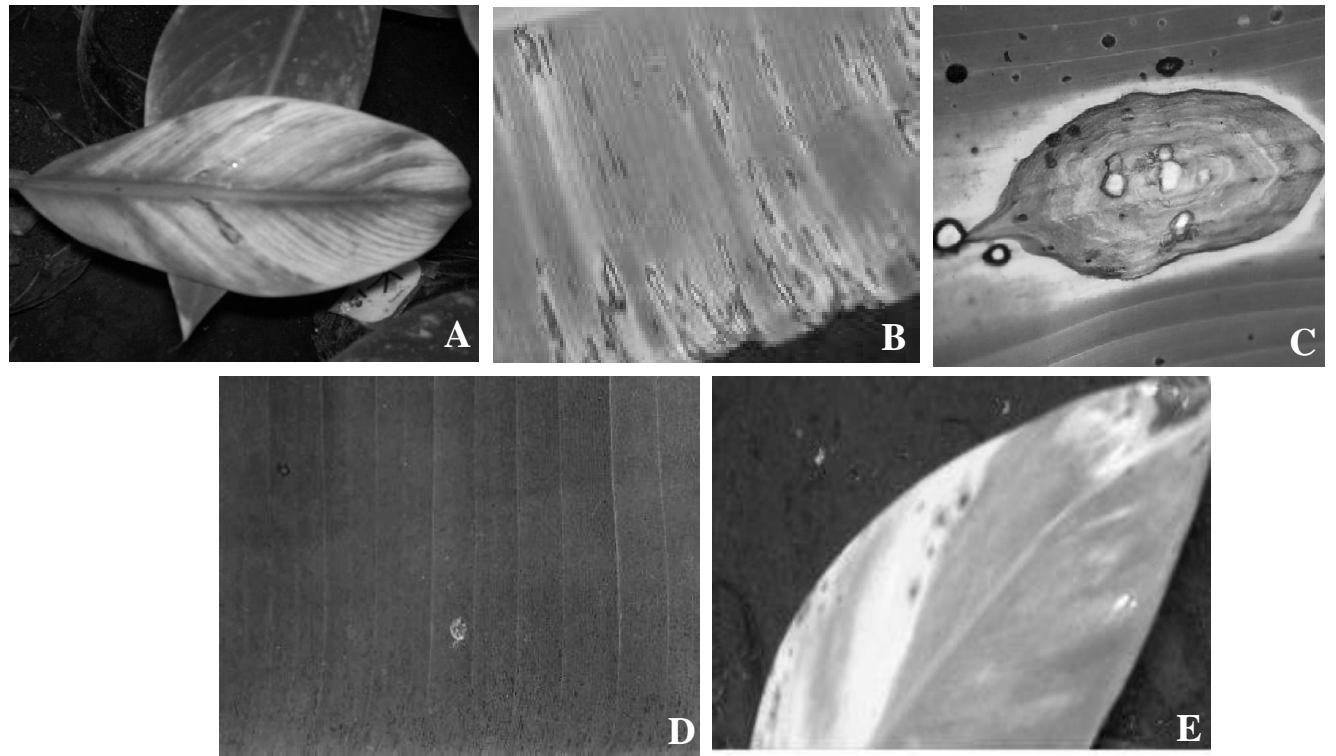

Gambar 1. Gejala penyakit pada bibit pisang. (A) Penyakit layu Fusarium, (B) Sigatoka, (C) bercak daun Cordana, (D) penyakit bercak daun Curvularia, dan (E) burik.
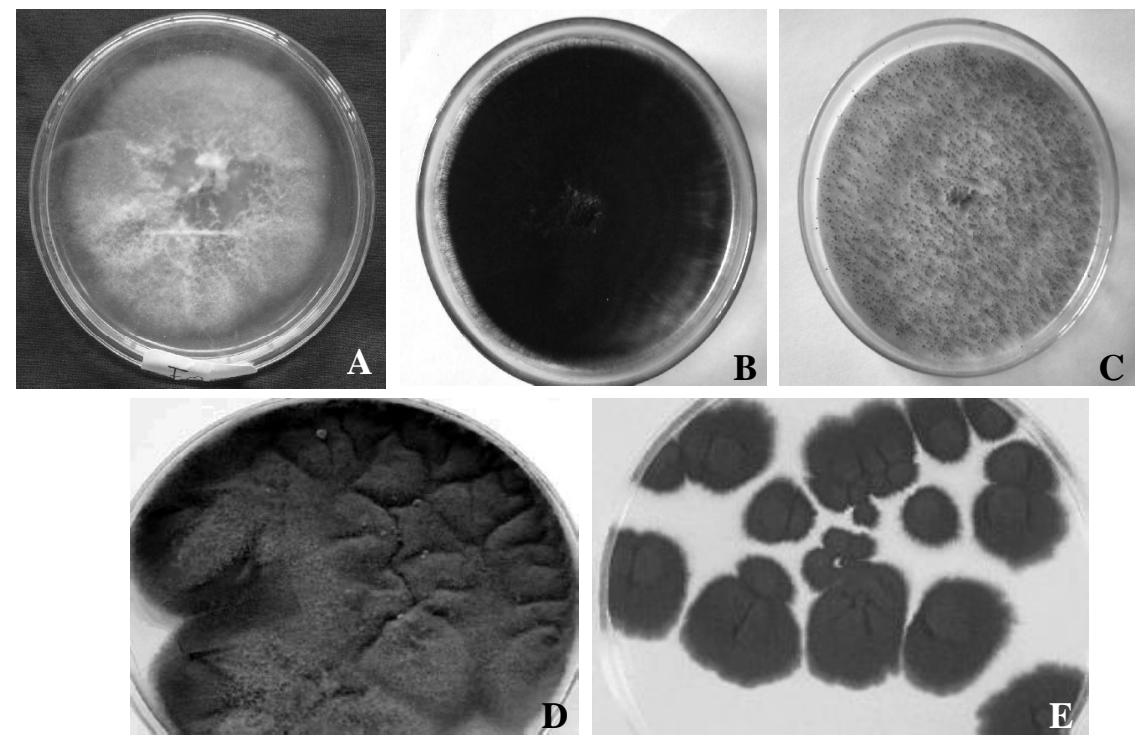

Gambar 2. Morfologi koloni jamur patogen pada daun bibit pisang. (A) Fusarium oxysporum f.sp. cubense, (B) Mycosphaerella musicola, (C) Cordana musae; (D) Curvularia lunata, dan (E) Cladosporium musae.

pendapat Crous (2009). Lebih lanjut dikatakan, jamur M. musicola membentuk koloni yang mencirikan sifat morfologinya.

Pada koloni jamur Cordana musae, warna kecoklatan terbentuk karena warna konidium dan konidiofornya (Gambar 2C). Hal ini sesuai dengan pendapat Meredith (1962) dan Soares et al. (2005), yaitu bahwa konidiofor jamur $C$. musae muncul secara langsung dari epidermis, sederhana, tegak, tebal, dan bewarna coklat tua di bagian dasar dan ke arah ujung warna menjadi coklat pucat atau agak tan-warna, yang menentukan warna koloni.

Koloni jamur Curvularia lunata berwarna kehitaman dengan permukaan halus (Gambar 2D). Sementara itu, koloni Cladosporium musae berwarna coklat kehijauan pada medium PDA (Gambar 2E). Hal ini sesuai dengan pernyataan Crous et al. (2005) bahwa kenampakan koloni $C$. musae adalah bewarna coklat kehitaman. 
Tabel 1. Konidium lima jamur patogen bibit tanaman pisang

\begin{tabular}{|c|c|c|c|}
\hline No. & Jamur patogen & Ukuran konidium $(\mu \mathrm{m})$ & B entuk konidium \\
\hline 1 & $\begin{array}{l}\text { Fusarium } \\
\text { oxysporum } \\
\text { f.sp.cubense }\end{array}$ & $(5-12) \times(2,3-3,50)$ & $\begin{array}{l}\text { Mikrokonidium bersel satu atau dua, tanpa } \\
\text { warna, lonjong atau agak memanjang. } \\
\text { Makrokonidium berbentuk lengkung, } \\
\text { bersekat 3-4, berdinding tipis, dan tanpa } \\
\text { warna. }\end{array}$ \\
\hline 2 & $\begin{array}{l}\text { Mycosphaerella } \\
\text { musicola }\end{array}$ & $(5-25) \times(2-6)$ & $\begin{array}{l}\text { coklat pucat, berbentuk tabung atau } \\
\text { berbentuk gada terbalik, lurus, melengkung, } \\
\text { atau bengkok, ujungnya tumpul atau } \\
\text { membulat, bersekat } 3-5 \text { atau lebih }\end{array}$ \\
\hline 3 & Cordana musae & $(12-21) \times(6-12)$ & $\begin{array}{l}\text { bulat telur terbalik, mempunyai } 1 \text { sekat, } \\
\text { kadang-kadang spora agak melekuk pada } \\
\text { sekat ini, berwarna agak kecoklatan }\end{array}$ \\
\hline 4 & Curvularia lunata & $(10-16) \times(4-6)$ & $\begin{array}{l}\text { berwarna coklat kehijauan, konidium } \\
\text { berwarna lebih gelap dari pada selnya. } \\
\text { Konidium terdiri atas 3-5 sel, cenderung } \\
\text { bengkok dengan bagian tengahnya } \\
\text { membesar }\end{array}$ \\
\hline 5 & $\begin{array}{l}\text { Cladosporium } \\
\text { musae }\end{array}$ & $(8-19) \times(3-5)$ & $\begin{array}{l}\text { Berwarna coklat kehijauan, konidium } \\
\text { berbentuk jorong, coklat pucat, bersel 1, } \\
\text { jarang bersel } 2\end{array}$ \\
\hline
\end{tabular}

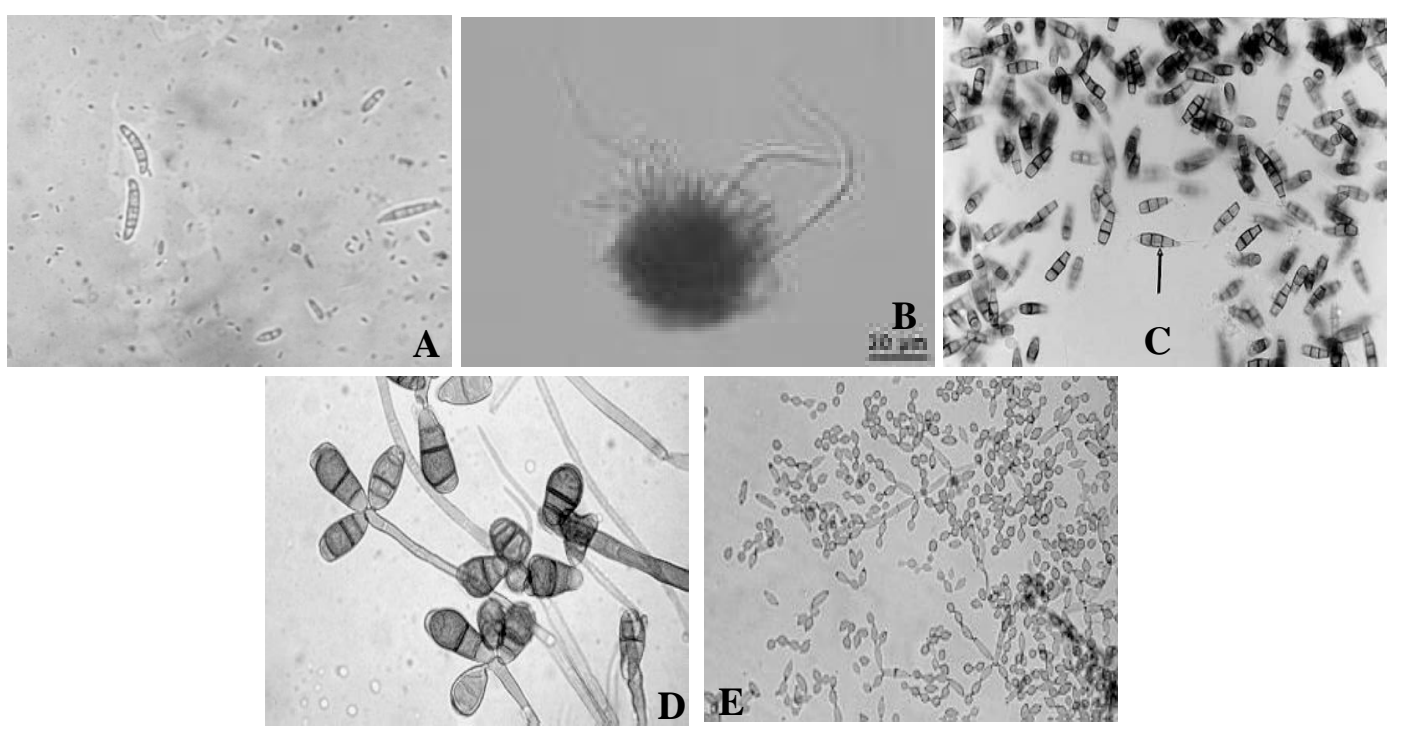

Gambar 3. Konidium beberapa jamur patogen pada daun bibit pisang. (A) F. oxysporum f.sp. cubense, (B) M. musicola, (C) Cordana musae, (D) Curvularia lunata, dan (E) Cladosporium musae.

Pengamatan Morfologi Patogen. Hasil pengamatan morfologi patogen dapat dilihat pada Tabel 1.

\section{Morfologi Fusarium oxysporum f. sp. cubense.} Jamur $F$. oxysporum f.sp. cubense membentuk mikrokonidium, makrokonidium, dan klamidospora (Gambar 3A). Mikrokonidium bersel satu atau dua, tanpa warna, lonjong atau agak memanjang, dan berukuran
$(5-12) \times(2,3-3,50) \mu \mathrm{m}$. Makrokonidium berbentuk sabit, kebanyakan bersel empat, tanpa warna, yang sesuai dengan pendapat Ploetz (2007) dan Smith (2007). Lebih lanjut dikatakan oleh Smith (2007), klamidospora bersel satu, jorong atau bulat, berukuran (7-13) x (7-8) $\mu \mathrm{m}$, dan terbentuk di tengah hifa atau pada makrokonidium, sering kali berpasangan. 
2. Morfologi Mycosphaerella musicola Mulder. Konidiofor membentuk berkas yang rapat, coklat pucat, lurus atau agak bengkok, jarang bercabang, tidak bersekat, tidak mempunyai bengkokan seperti lutut, menyempit ke ujung, tidak mempunyai berkas konidium, berukuran (5-25) x (2-6) $\mu \mathrm{m}$. Konidium coklat pucat, berbentuk tabung atau berbentuk gada terbalik, lurus, melengkung, atau bengkok, ujungnya tumpul atau membulat, bersekat 3-5 atau lebih (Goodwin et al., 2001; Crous, 2009). Morfologi konidium seperti nampak pada Gambar 3B.

3. Morfologi Cordana musae (Zimm.) Hohn. Jamur mempunyai konidiofor lurus atau agak bengkok, berwarna coklat pucat, bersekat dengan ukuran (100220) x (4-8) $\mu \mathrm{m}$, pada pangkalnya mempunyai bengkakan yang berukuran 6-10 $\mu \mathrm{m}$. Konidium bulat telur terbalik, mempunyai 1 sekat, kadang-kadang spora agak melekuk pada sekat ini, berwarna agak kecoklatan, dengan ukuran (12-21) x (6-12) $\mu \mathrm{m}$ (Gambar 3C). Konidium terbentuk pada bagian ujung dan bagian tengah konidiofor yang agak membengkak Meredith (1962). Hal ini didukung oleh pendapat Soares et al. (2005), yang mengatakan bahwa konidium dibentuk secara tunggal atau dalam kelompok seperti pembengkakan berwarna coklat di bagian ujung konidiofor.

4. Morfologi Curvularia lunata. Konidiofor berbentuk sederhana, berwarna coklat, konidium berwarna lebih gelap dari pada selnya. Konidium terdiri dari 3-5 sel, cenderung bengkok dengan bagian tengahnya membesar, bersifat parasit atau saprofit (Barnett \& Hunter, 1972). Morfologi konidium seperti nampak pada Gambar 3D.

5. Morfologi Cladosporium musae. Konidiofor lurus, coklat pucat, berukuran (70-185) x (4-7) $\mu \mathrm{m}$, cabang lurus, tanpa warna, dan berukuran (18-50) x (3-4) $\mu \mathrm{m}$. Konidium jorong, coklat pucat, bersel 1, jarang bersel 2, dan berukuran (8-19) x (3-5) $\mu \mathrm{m}$. Hal ini sesuai dengan pendapat Crous et al. (2005), yang menyatakan bahwa C. musae dinyatakan dalam Cladosporium karena konidium dan konidiofor yang berpigmen dan dibentuk di dalam rangkaian. Morfologi konidium seperti nampak pada Gambar 3E. Lebih lanjut dikatakan oleh Crous et al. (2005), berdasarkan ciri morfologi dan data molekul, khususnya urutan DNA, genus Cladosporium ditaksonomi ulang menjadi Metulocladosporium musae (E.W. Mason) Crous, Schroers, Groenewald, U. Braun $\&$ K. Schubert, comb. nov., dengan sinonim Periconiella sapientumicola Siboe.
Jenis Patogen yang Menyerang. Berdasarkan identifikasi, pada sampel diperoleh berbagai jenis jamur patogen yang menyebabkan penyakit pada bibit tanaman pisang, yang diamati pada 100 kultivar bibit pisang. Jamur tersebut antara lain: F. oxysporum f.sp. cubense, penyebab penyakit layu Fusarium; Mycosphaerella musicola Mulder, penyebab penyakit becak daun Mycosphaerella atau penyakit sigatoka; Cordana musae (Zimm.) Hohn, penyebab penyakit becak daun Cordana; Curvularia lunata, penyebab penyakit bercak daun; dan Cladosporium musae E.W. Mason, penyebab penyakit burik (speckle).

Masing-masing jamur patogen tersebut menyerang pada bibit pisang koleksi LIPI, dengan menunjukkan intensitas penyakit yang beragam. Jenis jamur patogen, jenis bibit pisang yang diserangnya, dan besarnya intensitas penyakit dapat dilihat pada Tabel 2 .

Pengamatan intensitas penyakit di lahan pembibitan menunjukkan bahwa masing-masing kultivar mempunyai intensitas penyakit yang berbeda, meskipun ada juga yang sama. Keragaman intensitas penyakit di setiap kultivar bibit pisang menunjukkan keragaman tingkat ketahanan tanaman terhadap serangan penyebab penyakit. Ketahanan tanaman yang berbeda menyebabkan kemampuan tanaman untuk menghadapi serangan penyebab penyakit yang berbeda pula. Setiap tanaman akan memberikan tanggapan terhadap serangan patogen, baik pada organ tanaman yang mulamula diserang (tanggap lokal) dan pada jarak di tempat yang tidak terinfeksi. Hal ini sesuai dengan pendapat Heil \& Bostock (2002), yang menyatakan bahwa tanggapan terhadap serangan patogen dapat terjadi secara lokal atau sistemik. Edreva (2004) menyatakan bahwa pengimbas ketahanan diefektifkan melalui pengikatan molekul yang diturunkan oleh patogen (elisitor) atau produk kimia dengan sisi penerima pada selaput atau dinding sel tanaman. Tanggapan ini dipacu oleh terbentuknya senyawa tertentu di dalam tanaman yang menentukan ketahanan tanaman terhadap serangan patogen (Edreva, 2004; Gomez et al., 2008; Soesanto \& Rahayuniati, 2009).

Pada Tabel 2 dapat dilihat bahwa dari 100 jenis kultivar yang diamati, F. oxysporum f.sp. cubense merupakan jamur patogen yang paling banyak dijumpai dengan intensitas serangan antara $1,4-72 \%$, diikuti intensitas serangan Culvularia lunata antara 1-32\%, Mycosphaerella musicola dengan intensitas 2-18\%, Cladosporium musae dengan intensitas 2-24\%, dan Cordana musae antara 3-23\%. Intensitas penyakit layu Fusarium tertinggi dijumpai pada kultivar ITC 0840 sebesar $72 \%$ dan intensitas penyakit becak daun 
Tabel 2. Jenis patogen dan intensitas penyakit yang ditimbulkannya pada berbagai kultivar pisang

\begin{tabular}{|c|c|c|c|c|c|c|c|c|}
\hline \multirow{3}{*}{$\begin{array}{l}\mathrm{N} \\
\mathrm{o}\end{array}$} & \multirow{3}{*}{$\begin{array}{c}\text { Jamur } \\
\text { Patogen }\end{array}$} & \multirow{3}{*}{$\begin{array}{c}\text { Nama } \\
\text { Penyakit }\end{array}$} & \multicolumn{6}{|c|}{ Kultivar Pisang dan Intensitas Pen yakit (\%) } \\
\hline & & & \multicolumn{2}{|c|}{ Koleksi } & \multirow[b]{2}{*}{ IP } & \multicolumn{2}{|c|}{ Orizalin } & \multirow[b]{2}{*}{ IP } \\
\hline & & & No. ITC & $\begin{array}{c}\text { Nama } \\
\text { Klon/Klutivar }\end{array}$ & & No. ITC & $\begin{array}{c}\text { Nama } \\
\text { Klon/Klutivar }\end{array}$ & \\
\hline \multirow[t]{20}{*}{1} & \multirow{20}{*}{$\begin{array}{l}\text { Fusarium } \\
\text { oysporum } \\
\text { f.sp. } \\
\text { cubense }\end{array}$} & \multirow{20}{*}{$\begin{array}{l}\text { Layu } \\
\text { Fusarium }\end{array}$} & ITC 0673 & $\mathrm{Sa}$ & 1.4 & ITC 0258 & Pisang Madu & 23 \\
\hline & & & ITC 0375 & Undu Jamau & 54 & ITC 0258 & Yangambi & 8 \\
\hline & & & ITC 0432 & Pamoti-on & 13 & ITC 0432 & Pamoti-on & 21 \\
\hline & & & - & AB Kunan & 6 & ITC 0375 & Undu Jamau & 42 \\
\hline & & & - & Ambon Mandar & 12 & ITC 0442 & Gu Nin Chio & 5 \\
\hline & & & - & Barangan \#1 & 14 & ITC 0507 & Pisang Madu & 20 \\
\hline & & & - & Barangan \#2 & 2 & ITC 0840 & Ku spaka & 72 \\
\hline & & & - & Jari Buaya \#2 & 2 & - & Jari Buaya & 26 \\
\hline & & & - & Kapas & 15 & ITC 0989 & Tagamor & 18 \\
\hline & & & - & $\begin{array}{l}\text { Kepok Kuning } \\
\text { Yogya }\end{array}$ & 2 & ITC 1253 & $\begin{array}{l}\text { Mjenga "Gros } \\
\text { Michel" diploid }\end{array}$ & 23 \\
\hline & & & - & $\begin{array}{l}\text { Klutuk Sukun } \\
\# 1\end{array}$ & 52 & ITC 0975 & $\begin{array}{l}\text { Pisang Gu Nin } \\
\text { Chio }\end{array}$ & 6 \\
\hline & & & - & $\begin{array}{l}\text { Klutuk Sukun } \\
\# 2\end{array}$ & 23 & - & Klutuk & 40 \\
\hline & & & - & Klutuk Wulung & 2 & - & Klutuk Wulung & 22 \\
\hline & & & - & Mas Jambe & 17 & - & Mas Lumut & 8 \\
\hline & & & - & Mas Jember & 6 & - & - & - \\
\hline & & & - & $\begin{array}{l}\text { Musa } \\
\text { acuminata var } \\
\text { banksii \#2.1 }\end{array}$ & 12 & - & $\begin{array}{l}\text { Musa acuminata } \\
\text { var banksii } \# 5.1\end{array}$ & 45 \\
\hline & & & - & $\begin{array}{l}\text { Musa } \\
\text { a cuminata var } \\
\text { banksii \#2.2 }\end{array}$ & 12 & - & $\begin{array}{l}\text { Musa acuminata } \\
\text { var banksii } \# 5.2\end{array}$ & 44 \\
\hline & & & - & $\begin{array}{l}\text { Pisang } \\
\text { Lampung }\end{array}$ & 30 & - & - & - \\
\hline & & & - & Raja Dengkel & 8.4 & - & - & - \\
\hline & & & - & Siam & 8 & - & - & - \\
\hline \multirow[t]{8}{*}{2} & \multirow{8}{*}{$\begin{array}{l}\text { Myosphae } \\
\text { rella } \\
\text { musicola } \\
\text { Mulder }\end{array}$} & \multirow{8}{*}{$\begin{array}{l}\text { Bercak } \\
\text { Daun } \\
\text { Mycospha } \\
\text { erella/ } \\
\text { Sigatoka }\end{array}$} & - & Kepok Jogja & 2 & ITC 0320 & Paka & 25 \\
\hline & & & - & Raja Sewu & 13 & ITC 0299 & Guyod & 2 \\
\hline & & & - & Raja Susu & 6 & ITC 0470 & Posok & 18 \\
\hline & & & - & Rejang \#2 & 7 & - & Rejang \#2 & 6 \\
\hline & & & - & - & - & ITC 0936 & $\begin{array}{l}\text { Musa acuminata } \\
\text { var. banksii }\end{array}$ & 14 \\
\hline & & & - & - & - & ITC 0974 & Bata bata & 10 \\
\hline & & & - & - & - & - & Mas Pinang & 13 \\
\hline & & & - & - & - & ITC 0679 & Pisang Sapon & 9 \\
\hline \multirow[t]{3}{*}{3} & \multirow{3}{*}{$\begin{array}{l}\text { Cordana } \\
\text { musae } \\
\text { (Zimm.) } \\
\text { Hohn }\end{array}$} & Bercak & ITC 0679 & Pisang Sapon & 3 & ITC 0281 & Akondro Mainty & 25 \\
\hline & & $\begin{array}{l}\text { Daun } \\
\text { Cordana }\end{array}$ & ITC 0689 & $\begin{array}{l}\text { Pisang } \\
\text { Bangkahulu }\end{array}$ & 9 & ITC 0777 & Pitu & 16 \\
\hline & & & ITC 0715 & Samba & 15 & - & Mas Jalil & 23 \\
\hline
\end{tabular}


Tabel 2. lanjuian

\begin{tabular}{|c|c|c|c|c|c|c|c|c|}
\hline & & & - & $\begin{array}{l}\text { Musa } \\
\text { acuminaata } \\
\text { var. } \\
\text { malaccensis \#1 }\end{array}$ & 16 & - & Mas Mangga & 18 \\
\hline & & & - & Raja Bulu & 22 & - & Mas Penjalin & 21 \\
\hline & & & - & - & - & - & Mas Rejang & 22 \\
\hline & & & - & - & - & - & Mas Rojo & 16 \\
\hline \multirow[t]{17}{*}{4} & \multirow{17}{*}{$\begin{array}{l}\text { Culvulari } \\
\text { a lunata }\end{array}$} & \multirow{17}{*}{$\begin{array}{l}\text { Bercak } \\
\text { Daun }\end{array}$} & ITC 0269 & Niyarma Yik & 10 & ITC 0260 & Colatina Ouro & 4 \\
\hline & & & ITC 0281 & $\begin{array}{l}\text { Akondro } \\
\text { Mainty }\end{array}$ & 6 & ITC 0266 & Sowmuk & 23 \\
\hline & & & ITC 0294 & Pitu & 8 & ITC 0279 & Bie yeng & 32 \\
\hline & & & ITC 0392 & Datil & 5 & ITC 0392 & Datil & 22 \\
\hline & & & - & B2 x E12 (E1) & 12 & ITC 0471 & Bebek & 14 \\
\hline & & & - & B2 x E12 (E2) & 1 & ITC 0553 & $2390-2$ & 18 \\
\hline & & & - & Dingin Lidi & 1 & ITC 0610 & Tuu Gia & 7 \\
\hline & & & - & $\begin{array}{l}\text { Dwarf } \\
\text { Cavendish }\end{array}$ & 4 & ITC 0990 & Vunapope & 12 \\
\hline & & & - & Dwarf Perfit & 5 & ITC 1004 & To'o & 16 \\
\hline & & & - & Jari Buaya ? 1 & 1 & ITC 1031 & Veinte Cohol & 17 \\
\hline & & & - & Mas Muli & 3 & ITC 1150 & $\begin{array}{l}\text { Morong } \\
\text { princesa }\end{array}$ & 22 \\
\hline & & & - & Ney Poovan & 4.8 & ITC 1455 & $\begin{array}{l}\text { Mshale } \\
\text { mlelembo }\end{array}$ & 3 \\
\hline & & & - & Ustrali Banten & 2 & ITC 1456 & Huti rb & 16 \\
\hline & & & - & - & - & - & Klutuk Sukun & 6 \\
\hline & & & - & - & - & - & $\begin{array}{l}\text { Klutuk } \\
\text { Warangan }\end{array}$ & 10 \\
\hline & & & - & - & - & - & Mas Sapoyono & 22 \\
\hline & & & - & - & - & - & Rejang \#1 & 15 \\
\hline \multirow[t]{9}{*}{5} & \multirow{9}{*}{$\begin{array}{l}\text { Cladospo } \\
\text { rium } \\
\text { musae }\end{array}$} & \multirow{9}{*}{$\begin{array}{l}\text { Penyakit } \\
\text { Burik } \\
(\text { speckle) }\end{array}$} & - & $\begin{array}{l}\text { Barangan } \\
\text { diploid }\end{array}$ & 15 & - & $\begin{array}{l}\text { Musa a cuminata } \\
\text { var. banksii \#3 }\end{array}$ & 24 \\
\hline & & & - & Kadali & 3 & - & - & - \\
\hline & & & - & Kepok \#1 & 8 & - & - & - \\
\hline & & & - & Kesan Pisan \#1 & 10 & - & - & - \\
\hline & & & - & Kesan Pisan \#2 & 2 & - & - & - \\
\hline & & & - & Mas 40 Hari & 9 & - & - & - \\
\hline & & & - & $\begin{array}{l}\text { Musa } \\
\text { acuminata var. } \\
\text { sumatrana }\end{array}$ & 8 & - & - & - \\
\hline & & & - & $\begin{array}{l}\text { Musa } \\
\text { acumninata var } \\
\text { malaccensis } \\
\# 2.1\end{array}$ & 4 & - & - & - \\
\hline & & & - & $\begin{array}{l}\text { Musa } \\
\text { acumninata var } \\
\text { malaccensis } \\
\# 2.2\end{array}$ & 10 & - & - & - \\
\hline
\end{tabular}


terendah ditemukan pada kultivar Dingin Lidi, B2 x E12 (E2), dan Jari Buaya “" 1 masing-masing sebesar $1 \%$. Hal ini diduga disebabkan kultivar Dingin Lidi, B2 x E12 (E2), dan Jari Buaya“"1 mempunyai ketahanan yang tinggi, sedangkan kultivar ITC 0840 memiliki ketahanan genetika yang rendah.

Tingginya intensitas penyakit layu Fusarium diduga dipengaruhi oleh kerentanan inang dan faktor lingkungan (Heil \& Bostock 2002; Smith 2007). Data pengamatan cuaca di lahan pembibitan menunjukkan suhu siang hari $40^{\circ} \mathrm{C}$, kelembaban $55 \%$, dan intensitas sinar matahari 29.000 lux. Kondisi iklim tersebut sesuai untuk perkembangan penyakit layu Fusarium. Hal ini karena perkembangan jamur $F$. oysporum f.sp. cubense, penyebab penyakit layu Fusarium, antara lain tergantung pada suhu udara dan kesuburan tanah. Penyakit layu Fusarium dapat berkembang cepat apabila didukung oleh suhu udara yang tinggi $40^{\circ} \mathrm{C}$, tanah yang kurang subur, dan $\mathrm{pH}$ tanah yang rendah atau masam (Ploetz, 2007; Smith, 2007).

Kelima jamur penyebab penyakit utama pada bibit tanaman pisang (Tabel 1) merupakan jamur yang selalu ditemukan khususnya pada daun tanaman pisang. Hal ini diduga bahwa jamur patogen tersebut adalah jamur endofit pada tanaman pisang. Photita et al. (2004) dan Soares et al. (2005) mengatakan bahwa beberapa genus jamur patogen merupakan endofit laten pada pisang, yang juga menyerang tanaman sejak dari pembibitan sampai tanaman di lapangan. Genus yang umum dijumpai sebagai patogen tanaman pisang adalah Cladosporium, Colletotrichum, Curvularia, Fusarium, Guignardia, Nigrospora, Phoma, dan Verticillium (Photita et al. 2001). Genus tersebut termasuk genus jamur yang banyak menyebabkan kerugian paling serius pada tanaman pisang, yaitu Fusarium oxysporum dan Colletotrichum gloeosporioides (Ploetz, 2000: Zakaria et al., 2009).

\section{SIMPULAN}

Berdasarkan pengamatan morfologi ada lima jenis jamur patogen yang menyebabkan penyakit bibit tanaman pisang, yang ditemukan pada 100 kultivar bibit pisang, yaitu: Fusarium oxysporum Schlecht. f.sp. cubense,penyebab penyakit layu Fusarium; Mycosphaerella musicola Mulder, penyebab penyakit becak daun Mycosphaerella atau penyakit Sigatoka; Cordana musae (Zimm.) Hohn, penyebab penyakit becak daun Cordana; Curvularia lunata, penyebab penyakit bercak daun; dan Cladosporium musae, penyebab penyakit burik (speckle). Pada 100 kultivar yang diamati, Fusarium oxysporum Schlecht. f.sp. cubense merupakan jamur patogen yang paling banyak dijumpai dengan intensitas serangan sebesar 1,4-72\%, diikuti Culvularia lunata dengan intensitas 1-32\%, Mycosphaerella musicola Mulder dengan intensitas 218\%, Cladosporium musae dengan intensitas 2-24\%, dan Cordana musae (Zimm.) Hohn dengan intensitas $3-23 \%$.

\section{SANWACANA}

Penelitian ini terlaksana atas bantuan berbagai pihak, untuk itu diucapkan terima kasih kepada Nuriyanto, Desi Sukmawati, Katarina Utami Nugraheni, Niken Purwandari, Chaerul Basir, M. Zaenudin, dan Utami atas bentuan teknis yang diberikan. Penelitian ini didanai dari Sub program Domestikasi Flora dan Fauna Indonesia, Program Kompetitif LIPI, untuk itu diucapkan terima kasih.

\section{DAFTAR PUSTAKA}

Barnett HL \& Hunter BB. 1972. Illustrated Genera of Imperfect Fungi. Burgess Publishing Company, Minneapolis, Minnasota.

Crous PW, Schroers H-J, Groenewald JZ, Braun U \& Schubert K. 2005. Metulocladosporiella gen. nov. for the causal organism of Cladosporium speckle disease of banana. Mycological Research 110:264-275. DOI: 10.1016/ j.mycres.2005.10.003.

Crous PW. 2009. Taxonomy and phylogeny of the genus Mycosphaerella and its anamorpoh. Fungal Diversity 38:1-24.

Dita MA, Waalwijk C, Buddenhagen IW, Souza Jr MT \& Kema GHJ. 2010. A molecular diagnostic for tropical race 4 of the banana fusarium wilt pathogen. Plant Pathology Doi: 10.1111/j.13653059.2009.02221.x.

Edreva A. 2004. A novel strategy for plant protection: Induced resistance. J. Cell and Mol. Biol.3:6169.

Gomez S, Onoda Y, Ossipov V \& Stuefer JF. 2008. Systemic induced resistance: a risk-spreading strategy in clonal plant networks? New Phytologist 179:1142-1153.

Goodwin SB, Dunkle LD \& Zismann VL. 2001. Phylogenetic analysis of Cercospora and Mycosphaerella based on the internal transcribed 
spacer region of ribosomal DNA. Phytopathol. 91:648-658.

Heil M \& Bostock RM. 2002. Botanical briefing: Induced systemic resistance (ISR) against pathogens in the context of infuced plant defence. Ann. of Botany 89:503-512.

Hermanto C \& Setyawati T. 2002. Pola sebaran dan perkembangan penyakit layu Fusarium pada pisang Tanduk, Rajasere, Kepok, dan Barangan. J. Hort. 12(1):64-70.

Jegger MJ, Eden-Green S, Thresh JM, Johanson A, Waller JM \& Brown AE. 1995. Bananas and plantain. Pp. 317-382. In: Gowean S. (Ed.), Bananas Disease. Chapman and Hall, London.

Kistler HC. 1997. Genetci diversity in the plantpathogenic fungus Fusarium oxysporum. Pythopathol. 87(4):474-479.

Meredith DS. 1962. Spore discharge in Cordana musae (Zimm.) Hohnel and Zygosporium oscheoides Mont. Ann. of Botany 26:233-241.

Nasir N, Jumjunidang, Eliesti F \& Mehlia Y. 2003a. Penyakit layu Panama pada pisang: Observasi ras 4 Fusarium oxysporum f.sp. cubense di Jawa Barat. J. Hort. 13(4):269-275.

Nasir N, Pittaway PA, Pegg KG \& Lisle AT. 2003b. A foliar rating system for comparing the resistance banana cultivars grown as tissue-culture plantlets in the laboratory to Fusarium wilt. Australasian Plant Pathology 32:521-526.

Nasir N, Jumjunidang \& Riska. 2005. Deteksi dan pemetaan distribusi Fusarium oxysporum f.sp. cubense pada daerah potensial pengembangan agribisnis pisang di Indonesia. J. Hort. 15(1):5057.

Photita W, Lumyong S, Lumyong P \& Hyde KD. 2001. Endophytic fungi of wild banana (Musa acuminata) at Doi Suthep Pui National Park, in Thailand. Mycological Research 105: 15081513 .ht t p://dx.doi org/10.1017/ S0953756201004968.
Photita W, Lumyong S, Lumyong P, McKenzie EHC \& Hyde, KD. 2004. Are a some endophytes of Musa acuminate latent pathogens? Fungal Diversity 16:131-140.

Ploetz RC. 2000. Panama disease: A classic and destructive disease of banana. (On-line) Plant Health Progress. Doi: 10.1094/PHP-2000-120401-HM.

Ploetz RC. 2007. Diseases of tropical perennial crops: Challenging problems in diverse environments. Plant Dis. 91(6):644-663.

Saravan T, Muthusamy M \& Marimuthu T. 2003. Development of integrated approach to manage the fusarial wilt of banana. Crop Protection 22:1117-1123.

Smith SN. 2007. An overview of ecological and habitat aspects in the genus Fusarium with special emphasis on the soil-borne pathogenic forms. Plant Pathol. Bull. 16:97-120.

Soares DJ, Nechet KL \& Barreto RW. 2005. Cordana versicolor $\mathrm{sp}$. nov. (dematiaceous hyphomycetes) causing leaf-spot on Canna denudate (Cannaceae) in Brazil, with observation on Cordana musae. Fungal Diversity 18:147-155.

Soesanto L \& Rahayuniati RF. 2009. Pengimbasan ketahanan bibit pisang Ambon Kuning terhadap penyakit layu fusarium dengan beberapa jamur antagonis. Jurnal Hama dan Penyakit Tumbuhan Tropika 9(2):130-140.

Ulloa M \& Hanlin RT. 2000. Illustrated Dictionary of Mycology. APS Press, St. Paul, Minnesota.

Urdaneta G LM, Delgado AAE \& y A Pineiro LS. 2002. Micobiota del filoplano en platano Harton (Musa AAB), en el municipio Francisco Javier Pulgar del estado Zulia, Venezuela. Rev. Fac. Agron. (LUZ) 19:95-108.

Zakaria L, Sahak S, Zakaria M \& Salleh B. 2009. Characterisation of Colletotrichum Species Associated with Anthracnose of Banana. Short Communication. Tropical Life Sciences Research 20(2): 119-125. 